\title{
Semi-Empirical Method for evaluating Risk of Liquefaction during earthquakes a Study Case of Rhiss Dam
}

\author{
Fatima Ezzahraa .LATIFI ${ }^{1 *}$, Khadija .BABA ${ }^{1}$, Lahcen. BAHI ${ }^{2}$, Soukaina.TOUIJRATE ${ }^{1}$ and \\ Choukri .CHERRADI \\ ${ }^{(1)}$ Civil Engineering and Environment Laboratory - High School of Technology, Sale, \\ ${ }^{(2)}$ Civil Engineering, Water, Environment and Geosciences Centre (CICEEG), Mohammadia School of Engineering,
}

Mohammed V University Rabat, Morocco Mohammed V University Rabat, Morocco

\begin{abstract}
Liquefaction is a hazardous and temporary phenomenon by which water saturated soil loses some or all of its resistance. The undrained conditions linked to the cyclic load increase the pores water pressure inside the soil and consequently reduce effective stress. As a result, the soil can no longer resist or hold the shear forces, and lead to enormous deformations that directly influence the stability of structures and infrastructures foundations. Since 1964, several semi-empirical methods have been invented to evaluate the liquefaction potential using the in-situ test results. This study is based on the correlation between experimental data results of Menard pressuremeter and SPT dynamic penetrometer tests. Samples used in this test come from the Rhiss dam located in the North of Morocco, 24 kilometers as the crow flies from the town of $\mathrm{Al}$ Hoceima and south of the foundations of a calcareous ridge. The studied area have high seismic activity and a high percentage of fine soil elements, which suggests the possibility of soil liquefaction. We present and discuss the results of applying Idriss and Boulanger, and Youd et al methods in the evaluation of liquefaction susceptibility.
\end{abstract}

\section{Introduction}

One of the most important causes of major structural and engineering works disorders during earthquakes is the development of liquefaction in saturated sandy soils. The main cause of soil liquefaction can be summarized as follows: if saturated sand undergoes ground vibrations, it tends to compact and decreases in volume. So, when drainage is impractical, soil pores pressure increases until it reaches an equal value to the total soil pressure. Therefore the effective pressure is cancelled, which makes the sand without resistance and thus develops a liquefaction state.

The case studied is based on the SPT tests experimental results of the RHISS dam, located in the North of morocco.

The aim of this paper is, on the one hand, to signal the phenomenon of liquefaction which is responsible of high level of soil instability in Morocco, especially in the North. On the other hand, to study the ability of semiempirical methods to correctly verify the susceptibility of liquefaction by calculating the safety factor using the cyclic stress approach.

\section{Semi-empirical methods used in the evaluation}

Nowadays, several semi-empirical methods are used to quantify and evaluate the potential of liquefaction [1-2]. This potential reflects the ability of soil to withstand cyclic shear forces and depends mainly on the relative density, grain size, soil texture, degree of saturation and magnitude of the earthquake.

These semi-empirical methods used to evaluate liquefaction potential are based on historical seismic observations, liquefaction-induced effects and in situ test results. They can be classified into three categories of approaches:

- Cyclic stress approach , [3, 4, 5, 6, 7]

- Cyclic deformation approach , [8-9]

- Energy approach. [10]

The cyclic stress is the most frequently used approach in practice to estimate resistance to soil liquefaction by calculating a Safety Factor (FS). That FS is obtained from the ratio between cyclic resistance $\mathbf{C R R}$ and cyclic constraint CSR.

The most frequently used tests for estimating the liquefaction potential are the static penetrometer test (CPT) and the dynamic penetrometer test (SPT).

However, the assessment of liquefaction potential, at first, was based on laboratory tests to understand the behavior of the soil samples in earthquakes. It should be noted that these samples are usually disrupted, which leads to changes the texture and structure of the soil grains and directly influences the resistance of the soil to liquefaction.

\subsection{Evaluating cyclic stress ratio (CSR)}

\subsubsection{Youd et al method}

Fatima Ezzahraa LATIFI: Fz.latifi@gmail.com 
CSR is the average shear stress in a layer $\left(\tau_{\text {avg }}\right)$ normalized to an effective vertical stress $\left(\sigma_{v}^{\prime}\right)$. It is presented for the first time by Seed and Idriss (1971) [11] by the following formula, which presents the basis for the three approaches:

$$
\operatorname{CSR}=\frac{\tau_{\mathrm{avg}}}{\sigma_{\mathrm{wo}}}=0,65\left(\frac{\mathrm{a}_{\mathrm{max}}}{\mathrm{g}}\right)\left(\frac{\sigma_{\mathrm{vo}}}{\sigma_{\mathrm{wo}}}\right) \mathrm{r}_{\mathrm{d}} \text { [12] }
$$

Where $a_{\max }$ is the maximum amplitude of the horizontal acceleration; $\sigma_{v 0}$ is the total vertical stress due to the weight of the overlying soils; $\sigma_{\text {v0 }}^{\prime}$ is the initial vertical effective stress; $g=9,81$ is the acceleration of gravity and $\mathrm{r}_{\mathrm{d}}$ is the stress reduction factor.

The stress reduction coefficient $r_{d}$ is expressed in terms of the depth by the following formula (Seed and Idriss 1971):

$$
r_{d}=\frac{\left(1-0,4113 z^{0,5}+0,04052 z+0,001753 z^{1,5}\right)}{\left(1-0,4177 z^{0,5}+0,05729 z-0,006205 z^{15}+0,00121 z^{2}\right)}
$$$$
\text { [11] }
$$

\subsubsection{Idriss and Boulanger method}

$\operatorname{CSR}=\frac{\tau_{\mathrm{avg}}}{\sigma_{\mathrm{v} 0}^{\prime}}=0,65\left(\frac{\mathrm{a}_{\max }}{\mathrm{g}}\right)\left(\frac{\sigma_{\mathrm{v} 0}}{\sigma_{\mathrm{v} 0}^{\prime}}\right) \frac{\mathrm{r}_{\mathrm{d}}}{M S F} \frac{1}{k_{\sigma}}$

The stress reduction coefficient is expressed in terms of the depth by the following formula:

$$
\begin{array}{ll}
\operatorname{Ln}\left(r_{d}\right)=\alpha(z)+\beta(z) M & \mathrm{z} \leq 34 \mathrm{~m} \\
r_{d}=0,12 \exp (0,22 M) & \mathrm{z}>34 \mathrm{~m}
\end{array}
$$

Where :

$$
\begin{aligned}
& \alpha(z)=-1,012-1,126 \sin \left(\frac{z}{11,73}+5,133\right) \\
& \beta(z)=0,106+0,118 \sin \left(\frac{z}{11,28}+5,142\right)
\end{aligned}
$$

The MSF factor, for this method, is expressed by Idriss (1999) by the following equation:

$$
M S F=6,9 \exp \left(\frac{-M}{4}\right)-0,058 ; \mathrm{MSF} \leq 1,8[14]
$$

$k_{\sigma}$ is the correction factor of the vertical effective stresses, adjusts the CSR with respect to the initial vertical effective stress and the relative density $D_{\mathrm{r}}$, it is expressed by Boulanger and Idriss :

$$
\begin{aligned}
& k_{\sigma}=1-C_{0} \ln \left(\frac{\sigma_{\mathrm{v} 0}^{\prime}}{P_{\alpha}}\right) \leq 1 \\
& C_{\sigma}=\frac{1}{18,9-2,55 \sqrt{N_{1,60}}} \leq 0,3
\end{aligned}
$$

\subsection{Evaluating cyclic resistance ratio (CRR) \\ 1.2.1. Youd et al method}

Semi-empirical procedures for liquefaction evaluation were initially developed using the results of the dynamic penetrometer (SPT) tests. The following detailed procedures are based on the developments of Seed and
Al [16-17] to obtain and adjust the number of SPT strokes and to obtain the values of CRR. The number of strokes obtained by the SPT test, as an indication of soil liquefaction characteristics, requires separating the effects of soil density and vertical effective stress on penetration resistance. Consequently, Seed and Al [18] included the normalization of penetration resistance in sand to a value equivalent to that of an atmosphere as a step in the semi-empirical procedure. This normalization currently takes the following form:

$$
N_{1,60}=C_{N} \times N_{1}
$$

Where the value of $N_{1}$ corresponds to the number of strokes of the SPT test and $C_{N}$ the coefficient of normalization of the penetration resistance.

$$
C R R=\frac{1}{34-N_{1.60}}+\frac{N_{1.60}}{35}+\frac{50}{\left(10 N_{1.60}+45\right)^{2}}-\frac{1}{200}
$$

\subsubsection{Idriss and Boulanger method}

The Idriss and Boulanger 2004 [4] method present a review and revaluation of several relationships in the potential assessment of liquefaction. According to Idriss and Boulanger 2004 [4] the value of CRR can be calculated as a function of $N_{1,60}$ using the following expression :

$$
C R R=\exp \left\{\frac{N_{1.60}}{14,1}+\left(\frac{N_{1,60}}{35}\right)^{2}-\left(\frac{N_{1,60}}{23,6}\right)^{3}+\left(\frac{N_{1,60}}{25,4}\right)^{4}-2,8\right\}_{[20]}
$$

\section{Case study}

Located in northern Morocco, Rif is undoubtedly the region most affected by various ground instabilities. This instability phenomenon, whose impact on the natural environment is certainly considerable, also constitute a major and permanent threat to road construction and infrastructures in this part of Morocco.

The Rhiss Dam site is located about $22 \mathrm{~km}$ upstream of its mouth and about $24.5 \mathrm{~km}$ as the crow flies from the town of Al Hoceima, the figure 1, represent a satellite view of our study area.

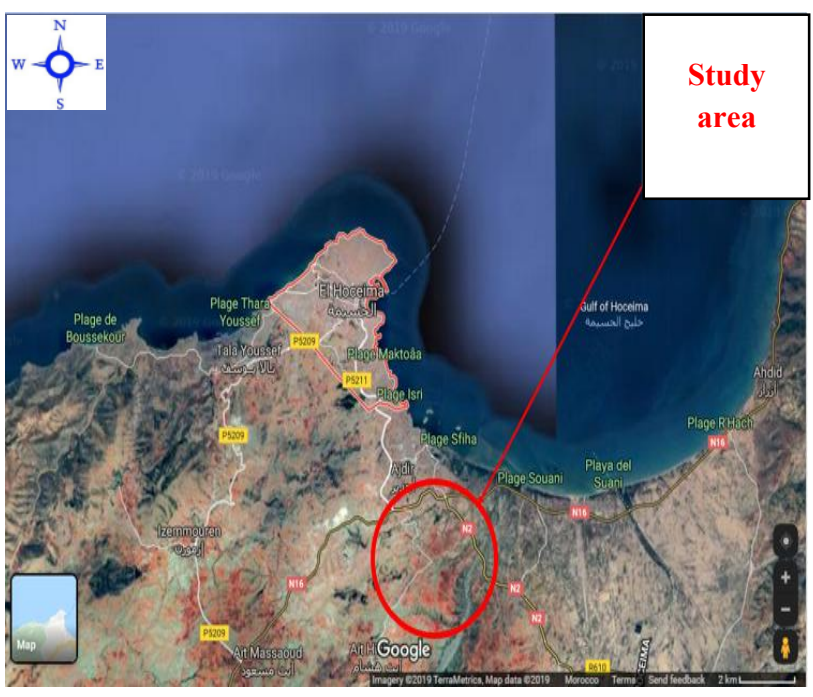

Fig.1. Satellite view of the studied site 


\subsection{Geological framework}

Geologically, The Rhiss dam site is located in this eastern part of the Rifaine chain, represented by:

- The marl limestone and marl flyschs of the Beni-bou yacoub unit, (Upper Cretaceous - medium

- Grey-black sericite schists with sandstone quartzite banks of the Kétama unit (SS). (Albo-aptien).

These two series form an anticlinal structure that is dumped towards the North and elongated in the shoreline direction, subtransversely to the direction of the valley where the different geological formations show an upright dip in the order of 40 to $60^{\circ}$ towards the downstream. This structure consists of a central part composed of quartzite intercalated shales forming the supports of the dam and borders composed of marl and marl limestone framing the shales and flushes upstream and downstream of the dam's right-of-way. The axis of the dam was chosen at the level of the downstream flank of the fold corresponding to the maximum tightening of the valley and where the dip of the geological formations is the most straightened 50 to $60^{\circ}$ downstream. In figure 2 we present the geological map of our study area.

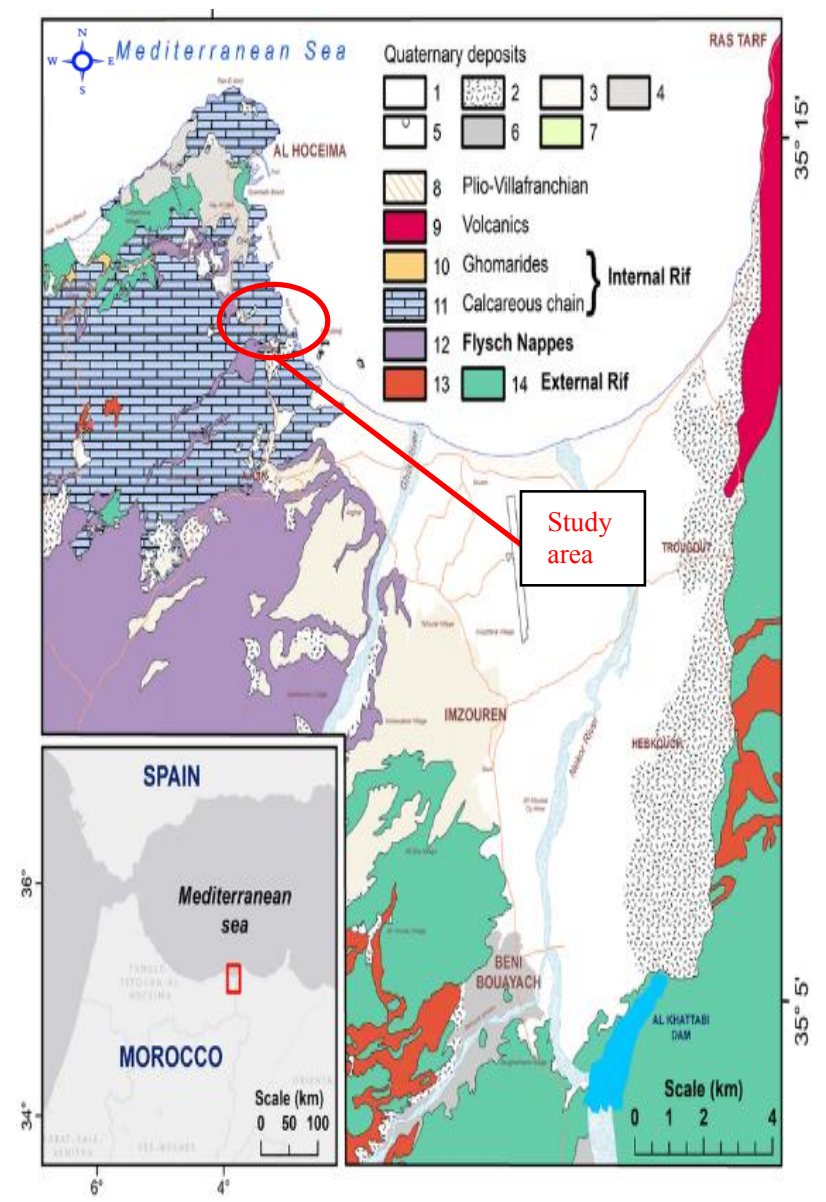

1 :Alluvium and silt; 2 :slope and scree deposits; 3 :unconsolidated sand $; 4$ :consolidated and dune $; 5$ :consolidated sand dune affected by subsidence and solifluction; 6 :encrusted surfaces; 7:conglomerates surface;8:conglomerates, sandstone and silts; 9:volcanics; 10:hard sandstone and conglomerates; 11:limestones and dolomites; 12:flyschs; 13 : clays and marls; 14:shales

Fig.2. Geological Map of the study area

\subsection{The region's seismicity}

The Al Hoceima region can currently be considered as the most seismic part of Morocco. As a result, it is among the most studied active areas along the border of diffuse African-Eurasian plates in the Western Mediterranean. Tectonic control of seismic activity in this area is still problematic.

Historical indications on the Al Hoceima region in particular suggest that seismic activity in this area existed in the past. Indeed, several earthquakes have been considered in the history of the region because of the scale of the disasters they caused.

The seismicity of the region $[21,22,23]$, dominated by a sinister decaying regime, does not align with any of the mapable faults on the surface, often with recent normal play. This may be a current fault or fault zone of the NNE-SSW general direction that does not affect the surface. The NNE-SSW fault or directional fault zone in NE-SW may well be the source of seismicity in this zone.

The seismic zoning map of Morocco shows that the AlHoceima area is located in the fifth zone, with a speed of $0.17 \mathrm{~m} / \mathrm{s}$.

\section{Results and discussions}

Since the results of the SPT test are not available, a correlation adopted by Honin et al [24] between Menard pressuremeter test and SPT dynamic penetrometer test, was chosen for the evaluation of CRR and CSR, using the data from five surveys of the pressuremeter Menard test in the study area.

In our case study, we estimate the safety factor by using two semi-empirical methods which are the Youd et al method, and the Idriss and Boulanger method, based on the cyclic stress approach, the result of each one are presented in the fig. 3 and fig. 4 .

According to fig. 3 and fig.4, we observed that the variation in the CSR curves of Youd et al method, and Idriss and Boulanger method is almost similar and the difference between the curves due essentially to the MSF factor in second method .

Fig. 5 and fig. 6 present a huge variation in the CRR curves using the two methods, which impact the values of safety factor.

According to the analysis of the different graphs in the fig.7 and fig.8, as interpretation we found the common layers which are the most affected in the depths between 11 and $16 \mathrm{~m}$, with a high liquefaction probability where the factor of security much less than 1 for the two method.

Fig. 9 and fig. 10 present the results obtained in terms of safety factor of the Rhiss dam in depth $11 \mathrm{~m}$, according to the analysis of the different surveys we found that the variation in the factor of security for SD7 is similar with a less risk of liquefaction, therefore for SD1 and SD3, we found that those areas present an average probability of liquefaction, finally for the other surveys SD5 and SD6 our safety factor presents values less than 1, essentially SD4 area with high risk for liquefaction according to the two method, which presents the first area influenced during earthquakes. 


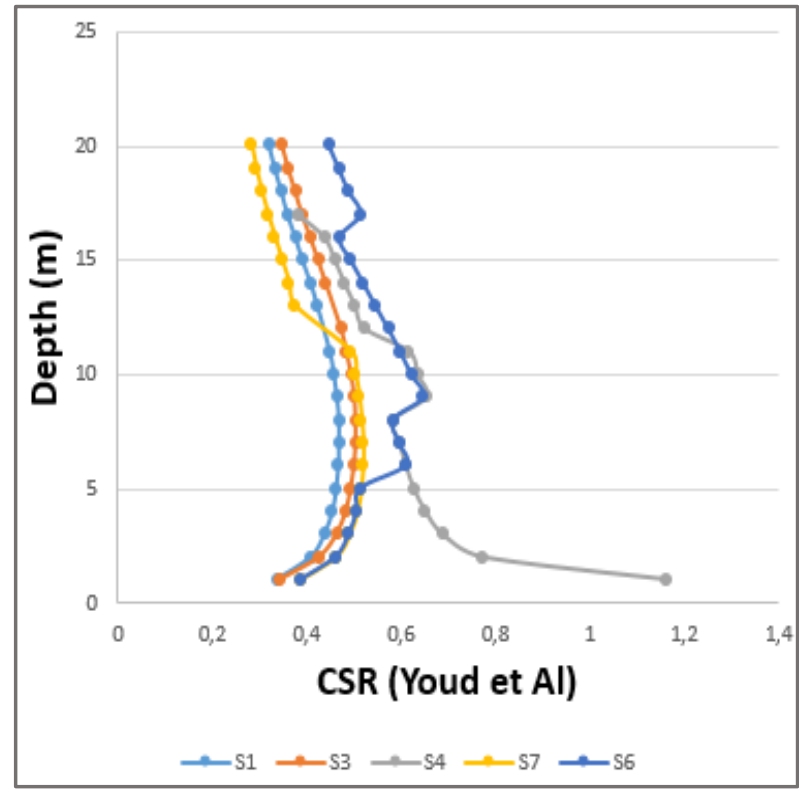

Fig.3 . CSR Values by Youd et al Method

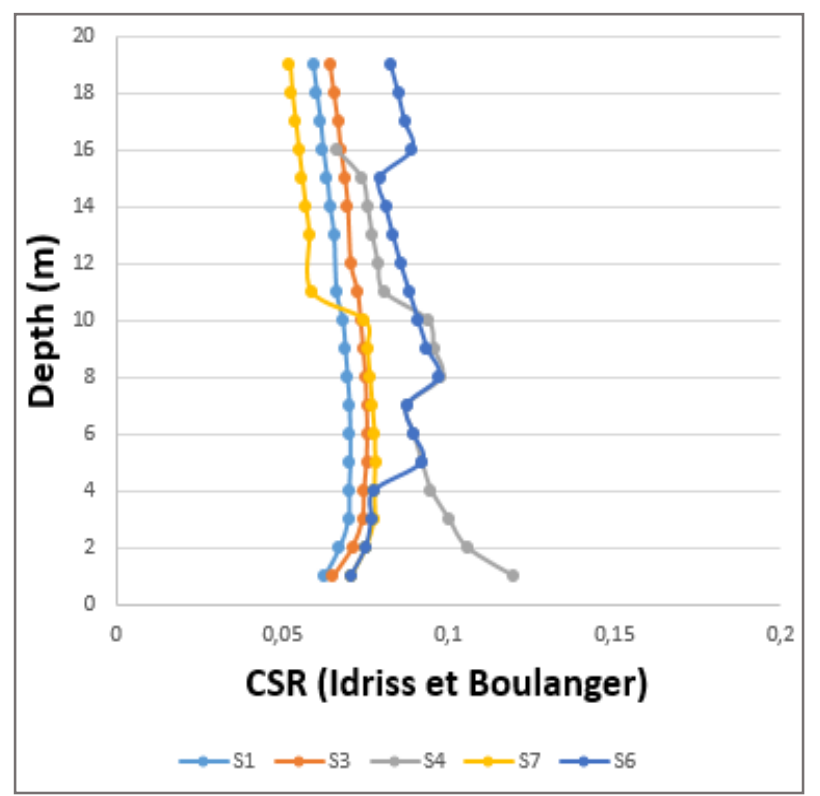

Fig.4 . CSR Values by Idriss and Boulanger Method

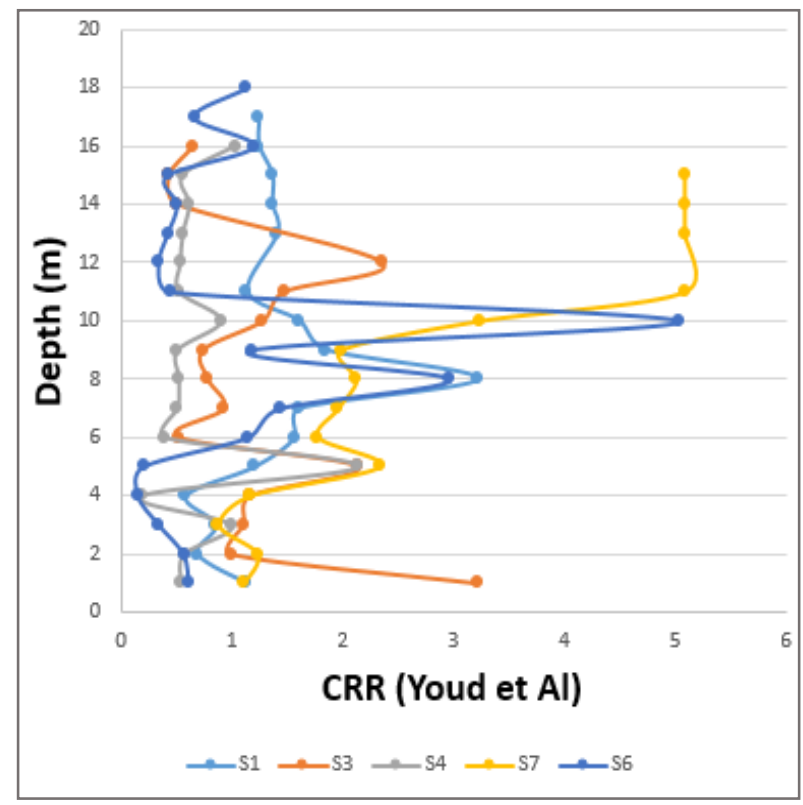

Fig.5 . CRR Values by Youd et al Method

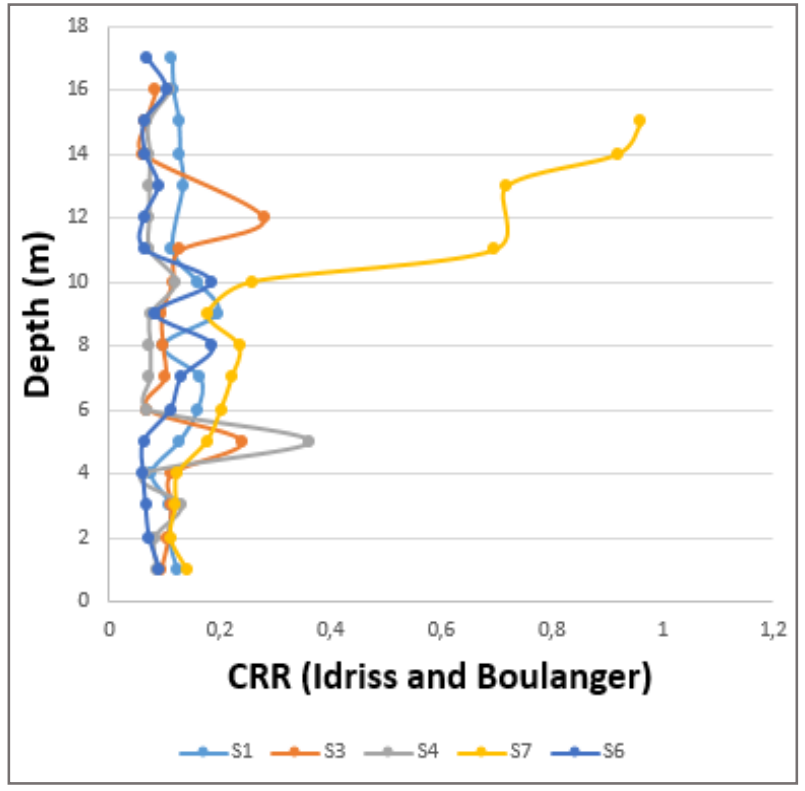

Fig.6 . CRR Values by Idriss and Boulanger Method

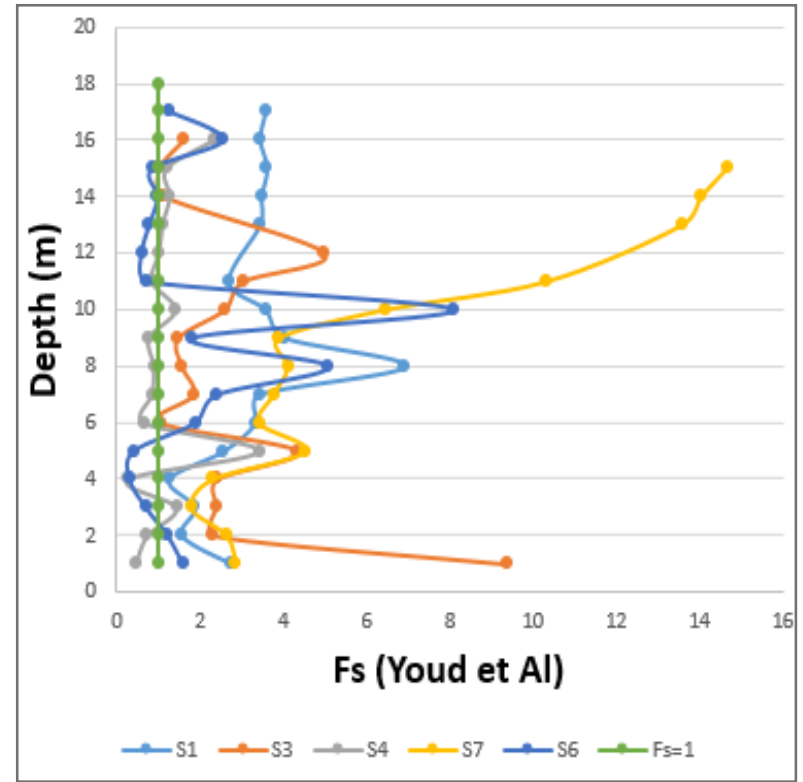

Fig.7 . Fs Values by Youd et al Method

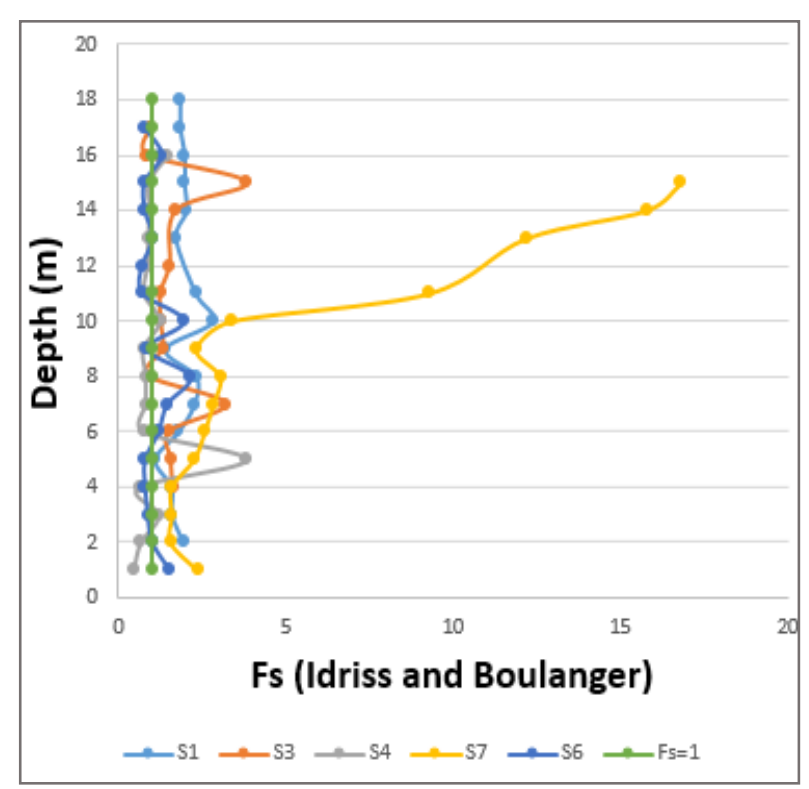

Fig.8 . Fs Values by Idriss and Boulanger Method 


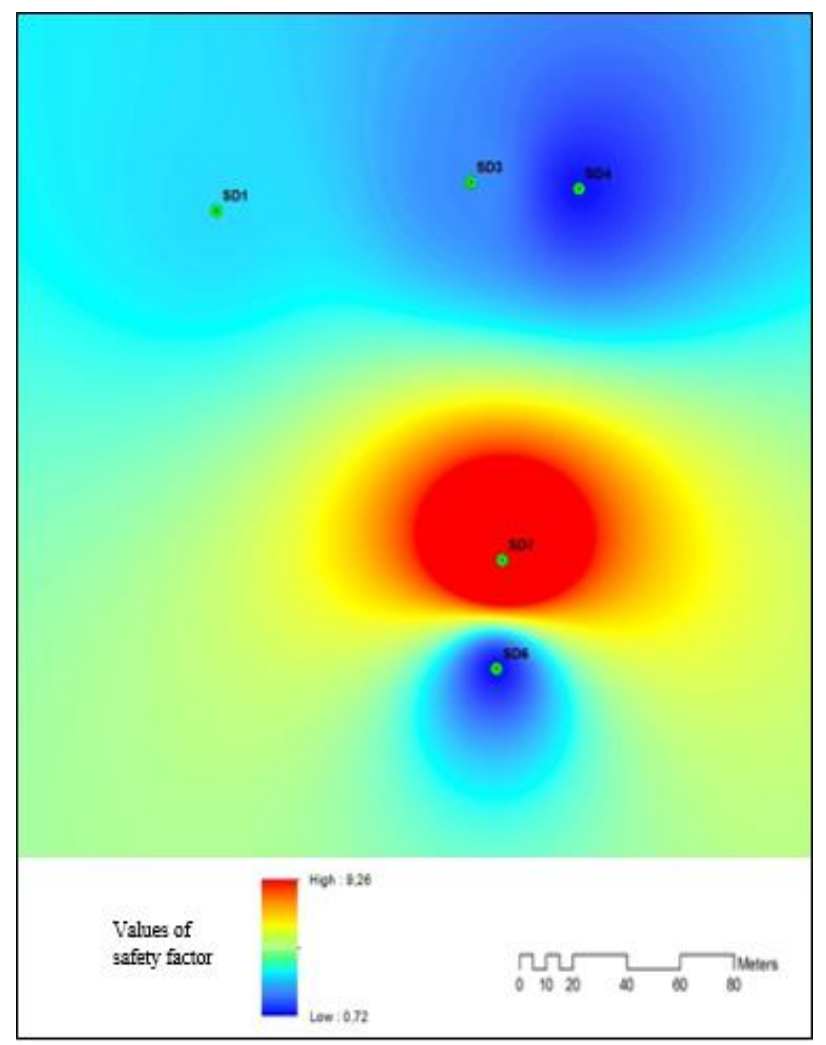

Fig.9 . Representation of Fs Values by Youd et al Method in depth $11 \mathrm{~m}$

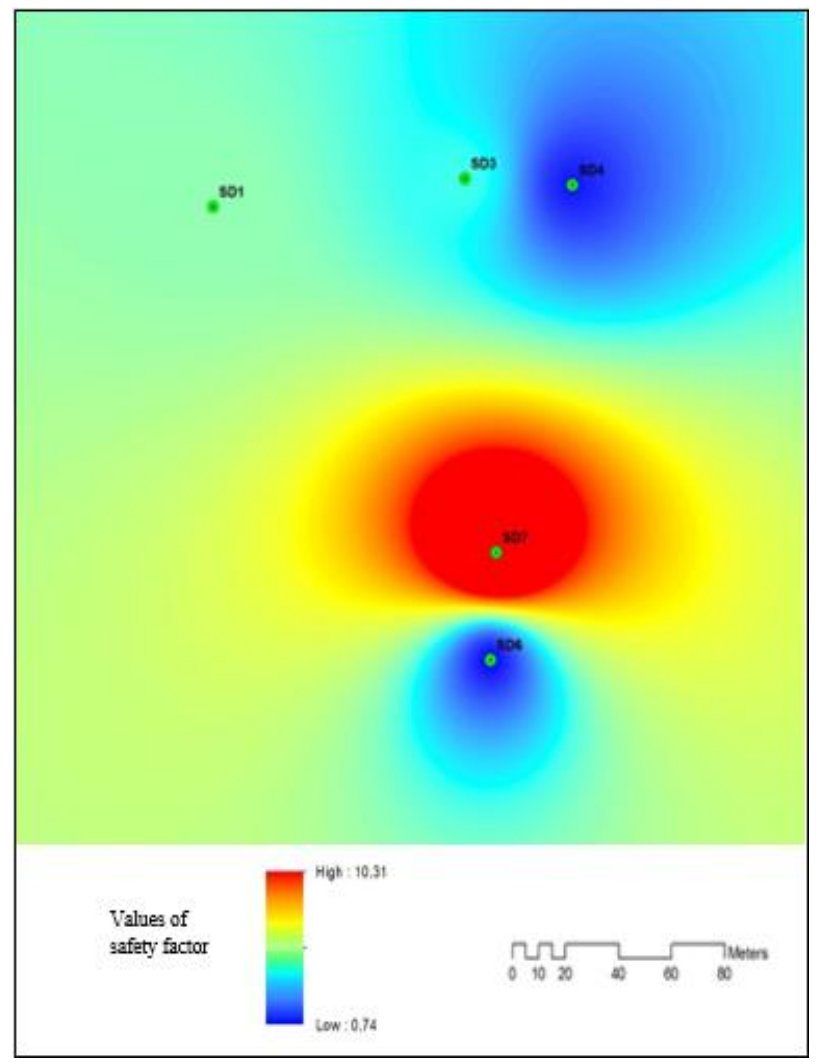

Fig.10 . Representation of Fs Values by Idriss and Boulanger Method in depth $11 \mathrm{~m}$

\section{Conclusion}

For liquefaction to occur, a combination of phenomena must be present, and first of all there must be an opportunity for liquefaction, which means that the energy of waves generated by the earthquake must be sufficient for the phenomenon to take place. The soil must also be susceptible to liquefaction and saturation underwater. If these three conditions are met, the liquefaction risk must be quantified for the seismic action in question. The consequences of liquefaction can then be assessed and soil treatment considered if necessary.

Based on the data from five surveys of the pressuremeter Menard test in the RHISS dam site, the susceptibility of liquefaction calculations were estimated by calculation the safety factor using two methods based on the cyclic stress approach which are the Idriss and Boulanger method and Youd et al method.

The results of these calculations allowed us to conclude that our studied site presents a high risk of liquefaction due the seismic context and geological of the region.

\section{References}

[1] TOUIJRATE S, BABA K, AHATRI M and BAHI L, 2018. The Liquefaction Potential Of Sandy Silt Layers Using CPT Tests: Case Study From The Casablanca-Tangier High-Speed Rail Line (LGV) In Morocco, International Journal of Civil Engineering \& Technology(IJCIET)-Scopus Indexed.Volume:9,Issue:10,Pages:1644-1656.

[2] TOUIJRATE S, BABA K, AHATRI M and BAHI L. Validation and Verification of Semi-Empirical Methods for Evaluating Liquefaction Using Finite Element Method, MATEC Web of Conferences 149, 02028 (2018), doi:10.1051/matecconf/201814902028, CMSS-2017.

[3] JUANG H, YUAN H, LEE D and LIN P, (2003). Simplified cone penetration test-based method for evaluating liquefaction resistance of soils. Journal of Geotechnical and Geoenvironmental Engineering, ASCE, 129(1), 66-80

[4] OLSEN R.S, (1997). Cyclic liquefaction based on the cone penetrometer test. In: Youd T.L, Idriss I.M, editors. Proceedings of the NCEER Workshop on Evaluation of Liquefaction Resistance of Soils. Technical Report NCEER-97-0022, Buffalo, NY: State University of New York at Buffalo; 1997. p. 225-276.

[5] ROBERTSON P.K and WRIDE C.E, (1998). Evaluating Cyclic Liquefaction Potential Using the Cone Penetration Test, Canadian Geotechnical Journal, 35(3), pp 442-459

[6] IDRISS I.M, BOULANGER R.W. In: Doolin D, editor. Semi-empirical procedures for evaluating liquefaction potential during earthquakes. Proc., 11th International conference on soil dynamics and earthquake engineering, and 3rd International conference on earthquake geotechnical engineering, vol. 1. Stallion Press; 2004. p. 32-56

[7] Youd T, IDRISS I.M, ANDRUS R.D, ARANGO I, CASTRO $G$ and CHISTIAN J.T, (2001). Liquefaction resistance of soils: Summary report from the 1996 NCEER and 1998 NCEER/NSF workshop on evaluation of liquefaction resistance of soils. Journal of Geotechnical and Geoenvironmental Engineering, ASCE, 127(10)

[8] ISHIBASHI I and ZHANG X, (1993). Unified dynamic shear moduli and damping ratios of sand clay. Soils and Foundations, 33 No 1, 182-191 
[9]DOBRY R and LADD R, (1980). Discussion to "'Soil Liquefaction and Cyclic Mobility Evaluation for Level Ground During Earthquakes,"" by H. B. Seed and "'Liquefaction Potential: Science versus Practice,"" by R. B, Peck, Journal of the Geotechnical Engineering Division, ASCE, Vol. 106, GT. 6, June, pp. 720-724

[10] NEMAT N.S et SHOKOOH A, (1979). Une Approche Unifiée à densification et Liquéfaction de Sable sans cohésion dans la taille cyclique, Journal Géotechnique canadien, Vol. 16, pp 659-678

[11] SEED H.B and IDRISS I.M. Simplified procedure for evaluating soil Liquefaction potential. J Soil Mech Found Div, ASCE 1971; 97(SM9):1249-73

[12] CHEN C.J, JUANG C.H, 2000. Calibration of SPTand CPT-based liquefaction evaluation methods. In: Mayne, P.W., Hryciw, R. (Eds.) Innovations and Applications in Geotechnical Site Characterization. Geotechnical Special Publication, vol. 97. ASCE, Reston, VA, pp. 49-64

[13] DAVIS R.O and BERRILL J.B, (1982). Energy dissipation and Seismic liquefaction in sands, Earthquake Engineering and structural Dynamics, Vol 10, pp.59-68.

[14] BENNANI et BENTAYEB A. Aménagement hydroagricole du bassin cotier Darader- Souiere, 21-44, 1979.

[15]BOULANGER R.W, IDRISS I.M. State normalization of penetration resistance and the effect of overburden stress on liquefaction resistance, Proc., 11th International Conf. on Soil Dynamics and Earthquake Engineering and 3rd International Conference on Earthquake Geotechnical Engineering, Univ. of California, Berkeley, CA,2004.

[16] SEED H.B, TOKIMATSU K, HARDER Jr.L.F, CHUNG $\mathrm{R}$, The Influence of SPT Procedures on Soil Liquefaction Resistance Evaluations, Report No. UCB/EERC-84/15, Earthquake Engineering Research Center, University of California, Berkeley, 1984

[17] SEED H.B, TOKIMATSU K, HARDER Jr.L.F, CHUNG R. Influence of SPT procedures in soil liquefaction resistance evaluations. J Geotech Eng, ASCE 1985; 111(12):1425-45

[18] SEED H.B, MORI K, CHAN C.K. Influence of Seismic History on the Liquefaction Characteristics of Sands, Report No. EERC 75-25, Earthquake Engineering Research Center, University of California, Berkeley, August 1975

[19] KIZSHIDA H. Damage to reinforced concrete buildings in Niigata city with special reference to foundation engineering - soil and foundation, Tokyo, vol,VI, $\mathrm{N}^{\circ} 1,71-88$

[20] KOISUMI Y. Change in density of sand subsoil case by the Niigata earthquake -soil and foundation, Tokyo, vol,VI, $\mathrm{N}^{\circ} 2, \mathrm{PP}, 38-44$

[21] AHATRI M, BABA K, TOUIJRATE K and BAHI L. MATEC Web of Conferences 149, 02041 (2018) https://doi.org/10.1051/matecconf/201814902041CMSS-2017. [22] AHATRI M, BABA K, TOUIJRATE K and BAHI L. The Influence of Spectral Responses on the Structures Heights, Proceedings of the 2nd GeoMEast International

Congress and Exhibition on Sustainable Civil Infrastructures, Egypt 2018 - The Official International Congress of the Soil-Structure Interaction Group in Egypt (SSIGE), Advances and Challenges in Structural Engineering pp 65-76.

[23] AHATRI M, BABA K, TOUIJRATE S and BAHI L, 2018. The Seismic Motion Parameters Effects On Response Spectra: Comparison Between El Centro 1940 And Imperial Valley 1979 Earthquakes, International Journal of Civil Engineering \& Technology (IJCIET) - Scopus Indexed.Volume:9, Issue: 10, Pages: 1610-1618.

[24] GONIN H, VANDANGEON P, LAFEUILLADE M.P. Etude sur les corrélations entre le standard et le pressiomètre penetration test, Rev. Franç. Géotech. ho 58, pp. 67-78 fianvier L992). 